\title{
Impaired glucose transport and protein kinase $B$ activation by insulin, but not okadaic acid, in adipocytes from subjects with Type II diabetes mellitus
}

\author{
C.M. Rondinone, E. Carvalho, C. Wesslau, U.P. Smith
}

The Lundberg Laboratory for Diabetes Research, Department of Internal Medicine, Sahlgrenska University Hospital, Gothenburg, Sweden

\section{Abstract}

Aims/hypothesis. To study the effects of insulin and okadaic acid, a serine/threonine phosphatase inhibitor which does not increase PI3-kinase activity, on the rate of glucose transport and protein kinase B activation in adipocytes from healthy subjects and subjects with Type II (non-insulin-dependent) diabetes mellitus.

Methods. Adipocytes were incubated with or without insulin or okadaic acid or both and glucose transport, protein kinase $\mathrm{B}$ activity, phosphorylation and protein expression measured.

Results. Insulin and okadaic acid alone increased glucose uptake to a similar degree in adipocytes from healthy subjects and, when combined, exerted a partial additive effect. The effect of insulin was reduced by about $60 \%$ in adipocytes from Type II diabetic patients, whereas the effect of okadaic acid was essentially unchanged and no further increase was seen when okadaic acid and insulin were combined. Oka- daic acid increased protein kinase $\mathrm{B}$ activity to a greater extent (two to threefold) than insulin but only slightly increased the serine phosphorylation of protein kinase B. Adipocytes from Type II diabetic subjects exhibited both an impaired sensitivity as well as a reduced total serine phosphorylation and activation of protein kinase $\mathrm{B}$ in response to insulin but protein kinase $\mathrm{B}$ activity in response to okadaic acid was intact.

Conclusion/interpretation. These results show that the ability of insulin to increase glucose transport and activate protein kinase B is reduced in fat cells from Type II diabetic subjects. Protein kinase B can, however, be activated by agents like okadaic acid which bypass the upstream defects in the insulin signalling pathway in Type II diabetic cells and, thus, increase glucose uptake. [Diabetologia (1999) 42: 819825]

Keywords PKB, insulin, okadaic acid, Type II diabetes, glucose transport.
Type II (non-insulin dependent) diabetes mellitus is characterized by insulin resistance in the major target tissues coupled with insufficient insulin secretion [1] producing an impaired uptake and metabolism

Received: 18 January 1999 and in revised form: 3 March 1999

Corresponding author: U.P. Smith, MD, PhD, The Lundberg Laboratory for Diabetes Research, Department of Internal Medicine, Sahlgrenska University Hospital, S-413 45 Gothenburg, Sweden

Abbreviations: PKB, Protein kinase B; GLUT-4, glucose transporter 4; PDK, phosphatidylinositol-dependent kinase. of glucose. The mechanisms for insulin resistance in Type II diabetes are not well understood, although the potential causes could be defects in the early and intermediate steps of the insulin signalling pathway. In animal models of Type II diabetes, there is considerable evidence for alterations in the early steps of insulin action. $\mathrm{Ob} / \mathrm{ob}$ mice and other insulin-resistant models of Type II diabetes have decreased insulin binding, decreased insulin receptor tyrosine kinase activity, decreased IRS-1 and IRS-2 protein content and tyrosine phosphorylation as well as decreased PI3-kinase activity leading to an impaired glucose transporter 4 (GLUT-4) translocation and glucose transport [2-5]. In addition, 
GLUT-4 protein content is reduced in some tissues including the adipose tissue. Recently, we have shown that adipocytes from Type II diabetic subjects have an impaired insulin-stimulated glucose transport as well as a large reduction in IRS-1 protein and tyrosine phosphorylation leading to a reduction in PI-3 kinase activity [6].

We have also shown that the serine/threonine phosphatase inhibitor, okadaic acid, that inhibits the activity of protein phosphatases 1 and 2A [7], exerts a full insulin-like effect in terms of increasing glucose transport activity through the translocation of GLUT-4 to the plasma membrane in human adipocytes [8]. This effect is independent of PI3-kinase activation, suggesting that alternate pathways exist to stimulate glucose uptake. Results from studies in skeletal muscle support this concept [9].

Recently, protein kinase B (PKB) (also known as $\mathrm{Rac}$ protein kinase or c-Akt) was recognized as a downstream target of PI3-kinase [10-12]. Protein kinase B was found to mediate some cellular responses induced by insulin and growth factors such as the inhibition of glycogen synthase kinase 3 [13], inhibition of apoptosis [14] and stimulation of glucose transport [15-17]. Furthermore, it has recently been shown that the $\operatorname{PKB} \beta$ isoform, which is the predominant isoform in adipocytes, is closely associated with the GLUT4-containing intracellular vesicles in rat fat cells [18]. Although the activation of PKB by growth factors and insulin is mediated through the activation of PI3-kinase [12], activation of PKB by protein phosphatase inhibitors, such as okadaic acid, is insensitive to wortmannin and independent of PI3-kinase [19].

In this study, we investigated the effects of insulin and okadaic acid on glucose transport, PKB phosphorylation and activity in adipocytes from healthy and Type II diabetic subjects. In addition, we examined whether insulin-stimulated (PI3-kinase dependent) $\mathrm{PKB}$ activity is changed in Type II diabetic adipocytes and, if so, whether it could be overcome by okadaic acid and the PI3-kinase - independent pathway.

\section{Materials and methods}

Materials. Human insulin was from Novo Nordisk (Copenhagen, Denmark) and okadaic acid from LC (Woburn, Mass., USA). Bovine serum albumin (BSA) (fractionV), collagenase, wortmannin and other fine chemicals were from Sigma (St. Louis, Mo., USA). Radiochemicals were from Amersham (Buckinghamshire, UK). Anti PKB polyclonal antibodies recognizing both $\mathrm{PKB} \alpha$ and $\mathrm{PKB} \beta$ or specific for $\mathrm{PKB} \beta$ were purchased from Upstate Biotechnology (Lake Placid, N.Y., USA). Antibodies recognizing the serine phosphorylated region of both $\mathrm{PKB} \alpha$ and $\mathrm{PKB} \beta$ as well as a control antibody recognizing the same but non-phosphorylated region were purchased from New England Biolabs (Beverly, Mass., USA). Protein A and A/G-Sepharose were from Santa Cruz (Santa Cruz, Calif., USA).
Subjects and source of adipose tissue. Specimens of human subcutaneous adipose tissue were obtained from the abdominal region of non-diabetic subjects $(n=9)$ and Type II diabetic subjects $(n=14)$. Both groups were of similar age and degree of obesity (healthy subjects; age $=50 \pm 5$ years, BMI $=29 \pm 3$ $\mathrm{kg} / \mathrm{m}^{2}$ and Type II diabetic subjects; age $=54 \pm 4$ years, $\mathrm{BMI}=32 \pm 2 \mathrm{~kg} / \mathrm{m}^{2}$ ). The subjects with Type II diabetes had been diabetic for $10 \pm 2$ years and their mean $\mathrm{HbA}_{1 \mathrm{c}}$ value was $7.7 \pm 0.3 \%$ (reference $3.5-5.3 \%$ ). They were treated with oral agents alone or combined with insulin $(n=6)$. The biopsy specimens were obtained in the fasting state in the morning and before the subjects took their regular medication. The last medication was taken at least $10 \mathrm{~h}$ before the biopsy. The biopsy specimens were placed in Medium 199 at $37^{\circ} \mathrm{C}$ containing $25 \mathrm{mmol} / \mathrm{l} \mathrm{HEPES,} 4 \% \mathrm{BSA}$ with $5.5 \mathrm{mmol} / 1$ glucose. The tissue was immediately transported to the laboratory for further processing. Informed consent was obtained from the subjects and the study was approved by the ethics committee of the Gothenburg University.

Preparation of isolated human adipose cells. Adipose cells were prepared according to methods previously described [6, $8]$. The tissue was cut into small fragments visibly free of connective tissue and blood. About $0.6 \mathrm{~g}$ of tissue was incubated at $37^{\circ} \mathrm{C}$ in Medium 199 containing $25 \mathrm{mmol} / \mathrm{l} \mathrm{HEPES,} 4 \%$ BSA, $5.5 \mathrm{mmol} / 1$ glucose and $0.8 \mathrm{mg} / \mathrm{ml}$ collagenase in a shaking water bath. After approximately $50 \mathrm{~min}$, liberated cells were filtered through a nylon mesh with a pore size of $400 \mu \mathrm{m}$ and washed four times in fresh BSA-containing medium and finally resuspended at $2 \%$ cytocrit. Cell size and number were measured as described previously [20]. Cells were then incubated with the indicated additions in the presence of $0.1 \mu \mathrm{mol} / 1 \mathrm{~N}^{6}$ (2-phenylisopropyl)-adenosine (PIA) and $1 \mathrm{U} /$ $\mathrm{ml}$ of adenosine deaminase (Boehringer, Mannheim, Germany).

Glucose transport in human adipose cells. Cellular uptake of $\left[{ }^{14} \mathrm{C}\right.$-U]-glucose was measured during 1 -h incubation of cells in glucose-free medium containing PIA and adenosine deaminase as indicated above at lipocrit 3-5\% as described [8]. After pre-incubation in the absence or presence of okadaic acid for $5 \mathrm{~min}$, the concentration of insulin $(6.9 \mathrm{nmol} / \mathrm{l})$ that stimulates to the maximum [6] was added to some tubes and after $15 \mathrm{~min}$ $0.86 \mu \mathrm{mol} / 1\left[{ }^{14} \mathrm{C}\right.$-U]-glucose was added. The cells were separated from the incubation medium after $1 \mathrm{~h}$ by centrifugation through silicone oil, the radioactivity associated with the cells was measured by scintillation counting and the rate of glucose transport calculated.

Protein kinase B phosphorylation. All cell incubations were carried out at $37^{\circ} \mathrm{C}$ in Medium 199 buffered with $25 \mathrm{mmol} / \mathrm{l}$ HEPES, $0.1 \mu \mathrm{mol} / 1 \mathrm{~N}^{6}$ (2-phenylisopropyl) - adenosine (PIA) and $1 \mathrm{U} / \mathrm{ml}$ of adenosine deaminase, with the addition of $4 \%$ BSA. Isolated human adipocytes were distributed into plastic vials (12-15\% cell suspension) in a final incubation volume of $500 \mu \mathrm{l}$. Cells were incubated with or without the indicated concentrations of okadaic acid for $5 \mathrm{~min}$ and then continued to be incubated in the presence or absence of $6.9 \mathrm{nmol} / \mathrm{l}$ insulin for $10 \mathrm{~min}$. Cells were immediately separated by centrifugation through silicone oil and lysed in $0.4 \mathrm{ml}$ lysis buffer containing $25 \mathrm{mmol} / \mathrm{l}$ TRIS-HCl, $\mathrm{pH} 7.4,0.5 \mathrm{mmol} / \mathrm{l}$ EGTA, $25 \mathrm{mmol} / 1 \mathrm{NaCl}, 1 \%$ Nonidet P-40, $1 \mathrm{mmol} / \mathrm{l} \mathrm{Na}_{3} \mathrm{VO}_{4}$, $10 \mathrm{mmol} / 1 \mathrm{NaF}, 0.2 \mathrm{mmol} / 1$ leupeptine, $1 \mathrm{mmol} / \mathrm{l}$ benzamidine and $0.1 \mathrm{mmol} / 1 \mathrm{4}$-(2-aminoethyl)-benzenesulfonylfluoride hydrochlorine (AEBSF) and rocked for $40 \mathrm{~min}$ at $4{ }^{\circ} \mathrm{C}$. Detergentinsoluble material was sedimented by centrifugation at $12000 \times g$ for $10 \mathrm{~min}$ at $4^{\circ} \mathrm{C}$ and the supernatants collected. 
Whole cell lysates were boiled in Laemmli buffer containing $55 \mathrm{mmol} / \mathrm{l}$ dithiothreitol for $5 \mathrm{~min}$. The samples were analysed by electrophoresis on $10 \%$ SDS-polyacrylamide gels, proteins transferred from the gel to nitrocellulose sheets and blocked in $5 \%$ fat-free milk. The blots were probed with the different primary antibodies according to the recommendations of the manufacturer and the proteins were detected by enhanced chemiluminescence using horseradish peroxidase-labelled secondary antibodies (Amersham, Buckinghamshire, UK), The intensity of the bands was quantified using a laser densitometer (Molecular Dynamics, Sunnyvale, Calif., USA).

Protein kinase B kinase activity. Detergent-insoluble material from the cell lysates was sedimented by centrifugation at $12000 \times g$ for $10 \mathrm{~min}$ at $4{ }^{\circ} \mathrm{C}$ and the supernatants were incubated overnight with $5 \mu \mathrm{g} /$ tube of affinity purified anti-sheep PKB kinase antibody recognizing both $\mathrm{PKB} \alpha$ and $\mathrm{PKB} \beta$. Subsequently, the incubation was continued for $1 \mathrm{~h}$ with $50 \mu \mathrm{l}$ of protein A/G-Sepharose beads. The beads were washed twice with Lysis Medium and resuspended in $100 \mu \mathrm{l}$ of PKB-kinase assay medium containing $25 \mathrm{mmol} / \mathrm{l}$ TRIS- $\mathrm{HCl}, \mathrm{pH} 7.5,0.5 \mathrm{mmol} / \mathrm{l}$ EGTA, $10 \mathrm{mmol} / 1 \mathrm{MgCl}_{2}, 1 \mathrm{mmol} / \mathrm{l}$ DTT and $0.1 \mathrm{mg} / \mathrm{ml} \mathrm{BSA}$. Protein kinase B kinase activity was assayed as described [12]. Briefly, $20 \mu \mathrm{l}$ aliquots of the resuspended immunoprecipitates were incubated for $10 \mathrm{~min}$ in assay medium supplemented with $74 \mathrm{KBcq}(2 \mu \mathrm{Ci})\left[\gamma_{-}{ }^{32} \mathrm{P}\right]$ ATP, $100 \mu \mathrm{mol} / \mathrm{l} \mathrm{ATP}, 2 \mathrm{ng} / \mathrm{ml}$ of the peptide inhibitor of cAMP-dependent protein kinase and $150 \mu \mathrm{g} / \mathrm{ml}$ myelin basic protein (MBP) or $100 \mu \mathrm{mol} / \mathrm{l}$ glycogen synthase kinase 3 (GSK-3) peptide (Upstate Biotechnology, Lake Placid, N. Y., USA) at $30^{\circ} \mathrm{C}$ in at total volume of $40 \mu$ l. Similar results were obtained with both substrates and, thus, the data were pooled. The reaction was terminated by spotting an aliquot of the samples on phosphocellulose paper filters (Whatman P81, Clifton, N.J., USA). After five washes in 1\% $(\mathrm{v} / \mathrm{v})$ orthophosphoric acid incorporation of radiophosphate was determined by liquid scintillation counting.

\section{Results}

Effect of insulin and okadaic acid on glucose transport. Incubation of non-diabetic human adipocytes with a maximum concentration of insulin $(6.9 \mathrm{nmol} /$ 1) [6] resulted in a $150 \%$ stimulation over basal transport rate (Fig.1). A maximum concentration of okadaic acid $(1 \mu \mathrm{mol} / \mathrm{l})$ produced a similar or greater effect and when the cells were incubated with both okadaic acid and insulin a partial additive effect was seen. The effect of insulin in Type II diabetic adipocytes was reduced by about $60 \%(p<0.01)$ compared with adipocytes from non-diabetic subjects whereas the effect of okadaic acid was not significantly $(p<0.1)$ reduced (Fig. 1). The effect of insulin and okadaic acid in combination was reduced by $50 \%$ $(p<0.01)$ in Type II diabetic adipocytes and was similar to that of okadaic acid alone. Thus, these findings support a preferential reduction in the effect of insulin on glucose transport in Type II diabetic cells but the effect of okadaic acid was essentially unchanged.

Protein kinase B phosphorylation in adipocytes from healthy and Type II diabetic subjects. We examined the effect of insulin or okadaic acid or both on the

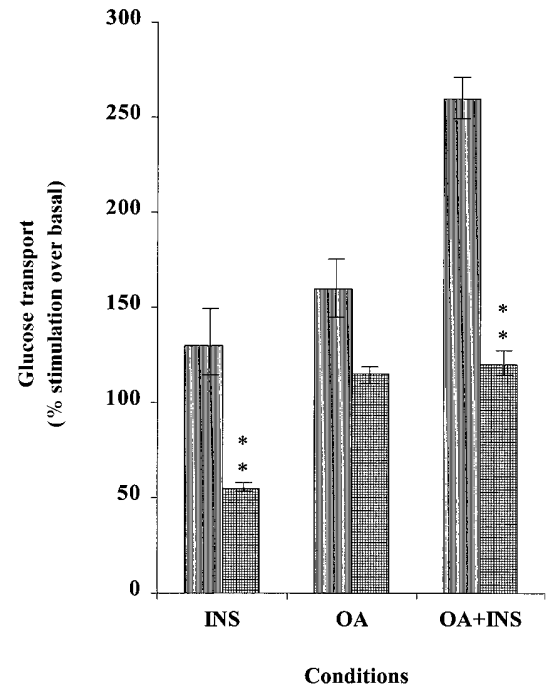

Fig. 1. Glucose transport in response to $6.9 \mathrm{nmol} / \mathrm{l}$ insulin or $1 \mu \mathrm{mol} / \mathrm{l}$ okadaic acid (OA) or both in fat cells from healthy or Type II diabetic subjects. Results are means \pm SEM of six separate studies done in duplicate. Significances of differences between control and Type II diabetic cells are also shown; $* * p<0.01$. Non-stimulated (basal) glucose transport was similar in both groups. $\amalg$ Healthy, 国Type II diabetic

serine phosphorylation of PKB using anti-serine specific antibodies recognizing the serine phosphorylated sites of both $\operatorname{PKB} \alpha$ and $\operatorname{PKB} \beta$ (serine 473 and 474 , respectively). Insulin, in contrast to okadaic acid alone, considerably increased the serine phosphorylation of $\mathrm{PKB}$ in non-diabetic adipocytes (Fig. 2A). The combination of these two agents produced an even greater effect. Densitometric scanning of all immunoblots showed that the serine phosphorylation of PKB in response to insulin alone was considerably impaired in adipocytes from Type II diabetic subjects by about $50 \%$ (relative intensity $6.25 \pm 0.54$ vs $11.59 \pm 1.86$ in Type II diabetic vs control, means \pm SEM, $p<0.01$ ) (Fig. $2 \mathrm{~A}$ ). In addition, the dose-response curve for this effect of insulin was noticeably shifted to the right in Type II diabetic $\left(\mathrm{EC}_{50} \sim 1.3 \mathrm{nmol} / \mathrm{l}\right)$ compared with control $\left(\mathrm{EC}_{50} \sim 0.2 \mathrm{nmol} / \mathrm{l}\right)$ cells documenting an impairment in the upstream signalling and activation (Fig. 2B). Densitometric scanning of these data (Fig. 2B-bottom) also showed the considerable reduction in serine phosphorylation in response to supramaximum insulin concentrations. To determine whether the reduction in serine phosphorylation observed in Type II diabetic adipocytes was due to changes in PKB protein expression, the same membranes were reprobed using a control anti-PKB antibody made against the same sequence. Scanning the immunoblots showed that total PKB protein expression (both $\mathrm{PKB} \alpha$ and $\mathrm{PKB} \beta$ ) was similar in the adipocytes from healthy and Type II diabetic subjects (data not shown). 

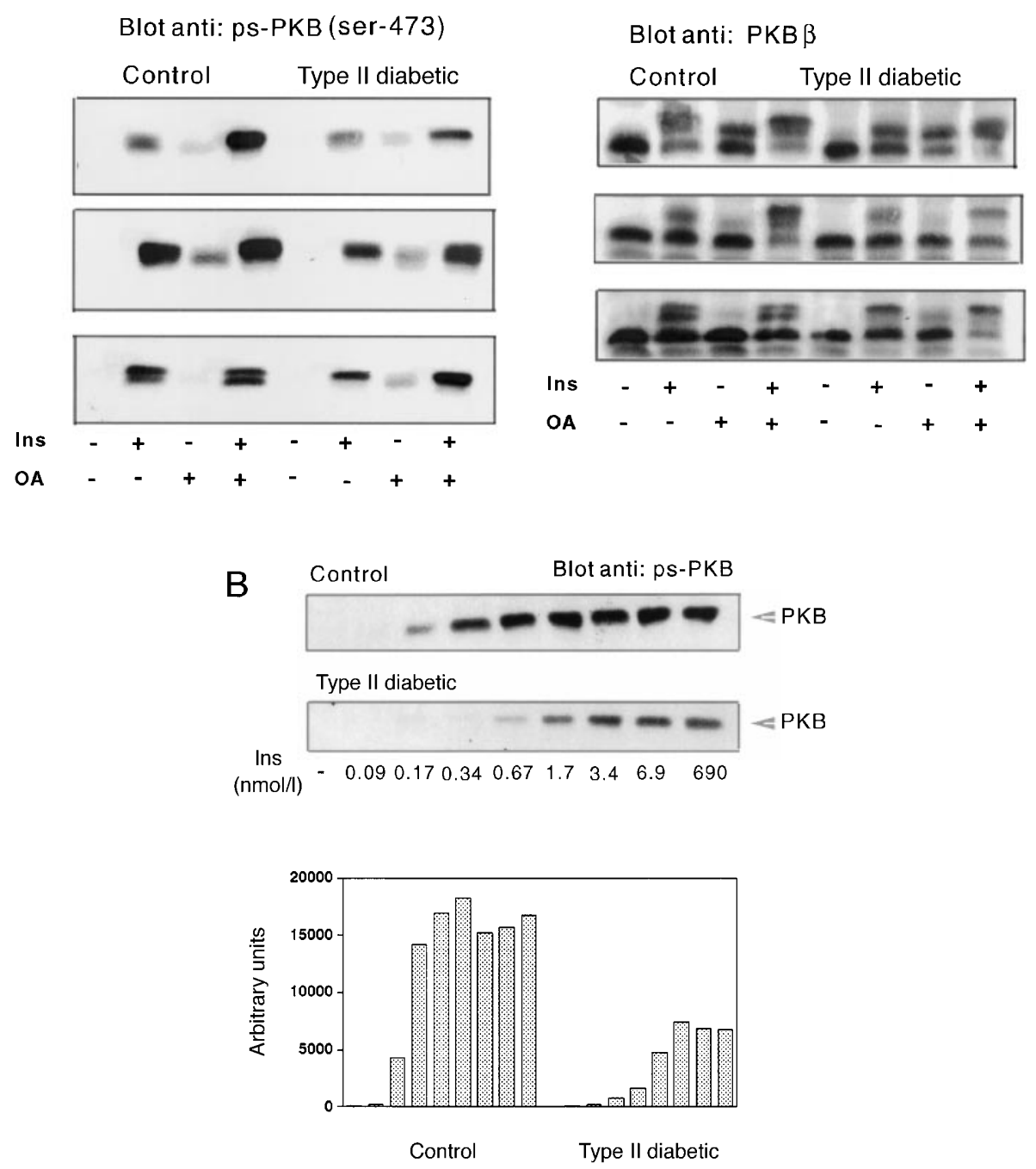

Fig. 2 A Serine phosphorylation (both $\mathrm{PKB} \alpha$ and $\mathrm{PKB} \beta$ ) (left) and electrophoretic mobility (right) of the $\operatorname{PKB} \beta$ isoform in lysates of fat cells from healthy and Type II diabetic subjects. The cells were preincubated for $10 \mathrm{~min}$ with $6.9 \mathrm{nmol} / \mathrm{l}$ insulin (INS) or $1 \mu \mathrm{mol} / 1$ okadaic acid (OA) or both. The proteins $(80 \mu \mathrm{g}$ in each lane) were separated on $10 \%$ SDS-PAGE, transferred to nitrocellulose membranes and immunoblotted with antibodies against the indicated proteins. B The dose-response curve for the ability of insulin to increase serine phosphorylation of PKB in healthy and Type II diabetic cells is also shown (top). A supramaximum insulin concentration (690 nmol/l) was used to verify a reduced insulin response. The results of scanning the intensity of the serine phosphorylation are also shown (bottom)

The protein expression was further examined by analysing the specific PKB isoforms in the fat cells. Protein kinase $\mathrm{B} \beta$ was the major isoform in both healthy and Type II diabetic cells accounting for around $70 \%$ of the PKB protein expression (data not shown). Cellular $\mathrm{PKB} \beta$ protein expression, relative to total cell protein, was also similar in both groups as verified by densitometric scanning of the immunoblots (relative intensity $10.1 \pm 2.0$ and $12.4 \pm 3.2$ in Type II diabetic vs healthy cells, means \pm SEM, $p>0.1$ ) but the degree of phosphorylation, measured as intensity of mobility-shifted bands in response to insulin, was reduced around $30 \%$. Okadaic acid alone and in combination with insulin produced a similar mobility shift in both groups suggesting a similar degree of phosphorylation. (Fig. 2A).

Protein kinase B kinase activity in Type II diabetic and non-diabetic cells. Surprisingly, in non-diabetic people, okadaic acid produced a greater increase in total $\mathrm{PKB}$ activity (both $\mathrm{PKB} \alpha$ and $\mathrm{PKB} \beta$ ) than insulin alone whereas both agents together had a partial additive effect (Fig. 3), similar to that seen for glucose transport. The insulin and the insulin + okadaic acid effects were reduced by about $50 \%(p<0.01)$ in adipocytes from Type II diabetic subjects compared with non-diabetic cells. The PKB kinase activity in response to okadaic acid alone was, however, not statis- 


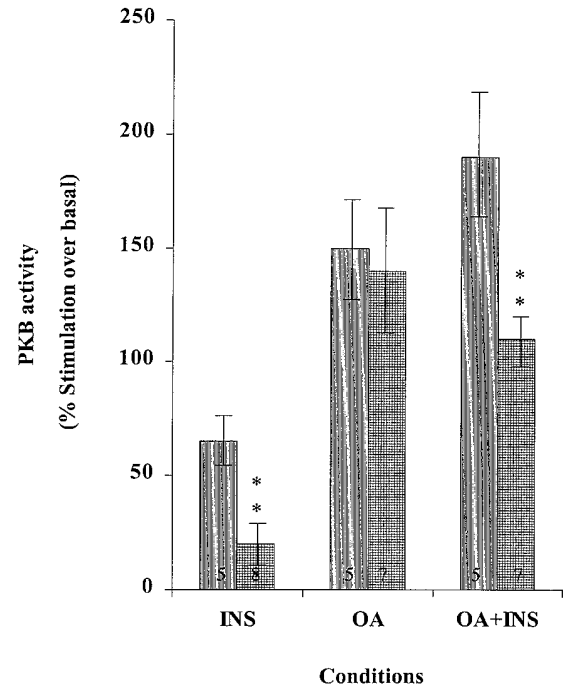

Fig.3. Total $\mathrm{PKB}$ activity (both $\mathrm{PKB} \alpha$ and $\mathrm{PKB} \beta$ ) in fat cells from non-diabetic and Type II diabetic cells preincubated for $10 \mathrm{~min}$ with $6.9 \mathrm{nmol} / \mathrm{l}$ insulin (INS) or $1 \mu \mathrm{mol} / 1$ okadaic acid (OA) or both. Protein kinase B activity was measured as described in the "Methods". Results are expressed as means \pm SEM of the indicated number of subjects. $* * p<0.01$. The subjects included in the PKB activity measurements were mostly the same as in Figure 1. $\|$ Healthy, 目 Type II diabetic

tically significantly different between non-diabetic and Type II diabetic adipocytes (Fig. 3).

\section{Discussion}

In this study, we provide evidence that insulin-stimulated PKB serine phosphorylation and total activity, but not protein expression, are considerably reduced in adipocytes from Type II diabetic compared with healthy subjects. This is not unexpected as we have shown previously that IRS-1 protein expression, insulin-stimulated tyrosine phosphorylation of IRS-1 and PI3-kinase activation are greatly reduced in Type II diabetic cells [6]. It is well established that PKB is a downstream target of PI3-kinase as dominant-negative mutants of the p85 regulatory subunit of PI3-kinase and inhibitors of PI3-kinase block insulin-stimulated PKB kinase activity [10-13]. Furthermore, overexpression of a constitutively active PI3-kinase activates PKB [21-23]. Another important finding of our study is that the PP1 and 2A phosphatase inhibitor, okadaic acid, bypasses and overcomes the upstream signalling defects in Type II diabetes producing a greater response than that of insulin with respect to both increasing PKB activity and glucose transport. Surprisingly, this occurs with only a minor increase in the serine phosphorylation of PKB. In addition, similar to recent findings with rat fat cells [18], $\operatorname{PKB} \beta$ is the major isoform in human fat cells, accounting for around $70 \%$ of the PKB protein expres- sion and it is normally expressed in adipocytes from Type II diabetic subjects.

Protein kinase B is activated through different mechanisms by insulin and okadaic acid. Protein kinase B stimulation by insulin is inhibited by wortmannin as PI3-kinase activation is required for the activation and translocation of PKB to the plasma membrane $[10-12,24,25]$. The PKB activation is due to the phosphorylation of threonine and serine sites $[26,27]$. Okadaic acid-stimulated glucose transport and PKB kinase activity are independent of PI3-kinase activity $[8,19]$. Interestingly, the extent of the serine phosphorylation was not directly correlated with PKB activity in response to okadaic acid. Okadaic acid induced a minor serine phosphorylation but a greater PKB activation than insulin alone. Consequently, activation of PKB in response to okadaic acid seems to be less dependent of serine phosphorylation of the kinase and thus probably occurs through threonine phosphorylation similar to what has been reported for vanadate [18] or through other pathways as suggested for isoproterenol [28].

A recent study showed that both insulin and IGF 1 induced PI3-kinase-dependent translocation of PKB to the plasma membrane [24]. The recently identified kinase phosphatidylinositol-dependent kinase (PDK) 1 phosphorylates PKB $\alpha$ on Thr308 although another kinase, called PDK2, phosphorylates it on Ser473 producing the full activation of the kinase [29-31]. The kinase PDK2 has not yet been identified definitively but recent data suggest that it could be similar to the integrin-linked kinase [32]. In Type II diabetic adipocytes, both the serine phosphorylation and the activation of PKB in response to insulin are impaired. This can be attributable to an impairment in the activation of PDK2 kinase activity, also dependent on PI3-kinase, as well as to an impaired activation of PDK1. Interestingly, the doseresponse curve for the ability of insulin to increase the serine phosphorylation of PKB was similar to the metabolic effect of insulin and was noticeably shifted to the right in Type II diabetic cells. These data are consistent with the upstream signalling defect in Type II diabetic cells that we reported previously [6]. Furthermore, these data support PKB being closely linked to insulin-stimulated glucose transport and lacks the redundancy found for other upstream kinases.

Okadaic acid activates both PKB and glucose transport in human adipocytes to a greater extent than insulin, in particular in Type II diabetic cells. These findings are consistent with the concept that PKB has a critical role in the activation of glucose transport and GLUT4 translocation. Our recent findings with a novel PKB inhibitor support this concept [33] although another study [34], using a dominant negative PKB mutant, did not find insulin-stimulated glucose transport to be abolished. 
The present study also supports the concept that glucose transport can be activated through alternate pathways (PI3-kinase dependent/independent) presumably leading to a common end point such as PKB activation. Furthermore, it should be emphasised that a reduced GLUT4 protein content has been shown in Type II diabetic fat cells [6]. Although this probably reflects the reduced "maximum" rate of glucose transport seen in the presence of insulin + okadaic acid, the present data also clearly show that an impaired intracellular signalling mechanism(s) for insulin has an important role for the insulin resistance related to the activation of glucose transport in Type II diabetic fat cells. A recent study in human skeletal muscle also showed an impairment in PKB activation in response to a high insulin concentration [35] whereas in another study no difference was seen after infusion of a physiological insulin concentration [36]. Further studies are required to elucidate whether this inconsistency is due to differences in the patients included, such as degree of glucose control, or to other differences in the experimental conditions.

In conclusion, the present study shows that the effect of insulin, but not okadaic acid, on both glucose transport and PKB activation is severely impaired in adipocytes from Type II diabetic subjects. The data also provide further evidence for the existence of different pathways to stimulate glucose transport, probably through the activation of PKB.

Acknowledgements. This study was supported by grants from the Swedish Medical Research Council (Project B-3506), the Swedish Diabetes Foundation, the Novo/Nordisk Foundation, the Tore Nilsson Foundation, the IngaBritt and Arne Lundberg Foundation and the European Community (project BMH4-CT96-0751). U.P. Smith is a Fogarty Scholar-in-Residence at the National Institutes of Health.

\section{References}

1. DeFronzo RA, Bonadonna RC, Ferrannini E (1992) Pathogenesis of NIDDM, a balanced overview. Diabetes Care 15: 318-368

2. Kerouz NJ, Horsch D, Pons S, Kahn CR (1997) Differential regulation of insulin receptor substrates-1 and -2 (IRS-1 and IRS-2) and phosphatidylinositol 3-kinase isoforms in liver and muscle of the obese diabetic (ob/ob) mouse. J Clin Invest 100: 3164-3172

3. Heydrick SJ, Jullien D, Gautier N et al. (1993) Defect in skeletal muscle phosphatidylinositol-3-kinase in obese insulin-resistant mice. J Clin Invest 91: 1358-1366

4. Folli F, Saad MJ, Backer JM, Kahn CR (1993) Regulation of phosphatidylinositol 3-kinase activity in liver and muscle of animal models of insulin-resistant and insulin-deficient diabetes mellitus. J Clin Invest 92: 1787-1794

5. Garvey WT, Maianu L, Huecksteadt TP, Birnbaum MJ, Molina JM, Ciaraldi TP (1991) Pretranslational suppression of a glucose transporter protein causes insulin resistance in adipocytes from patients with non-insulin-depen- dent diabetes mellitus and obesity. J Clin Invest 87: 1072-1081

6. Rondinone C, Wang L-M, Lönnroth P, Wesslau C, Pierce JH, Smith U (1997) Insulin receptor substrate (IRS) 1 is reduced and IRS-2 is the main docking protein for phosphatidylinositol 3-kinase in adipocytes from subjects with noninsulin-dependent diabetes mellitus. Proc Natl Acad Sci USA 94: 4171-4175

7. Bialojan C, Takai A (1988) Inhibitory effect of a marinesponge toxin, okadaic acid, on protein phosphatases. Specificity and kinetics. Biochem J 256: 283-290

8. Rondinone C, Smith U (1996) Okadaic acid exerts a full insulin-like effect on glucose transport and glucose transporter 4 translocation in human adipocytes. J Biol Chem 271: 18148-18153

9. Yeh JI, Gulve EA, Rameh L, Birnbaum MJ (1995) The effect of wortmannin on rat skeletal muscle. Dissociation of signaling pathways for insulin- and contraction-activated hexose transport. J Biol Chem 270: 2107-2111

10. Burgering BM, Coffer PJ (1995) Protein kinase B (c-Akt) in phosphatidylinositol-3-OH kinase signal transduction. Nature 376: 599-602

11. Franke TF, Yang SI, Chan TO et al. (1995) The protein kinase encoded by the Akt proto-oncogene is a target of the PDGF-activated phosphatidylinositol 3-kinase. Cell 81: 727-736

12. Kohn AD, Kovacina KS, Roth RA (1995) Insulin stimulates the kinase activity of RAC-PK, a pleckstrin homology domain containing ser/thr kinase. EMBO J 14: 4288-4295

13. Cross DA, Alessi DR, Cohen P, Andjelkovich M, Hemmings BA (1995) Inhibition of glycogen synthase kinase-3 by insulin mediated by protein kinase B. Nature 378 : 785-789

14. Dudek H, Datta SR, Franke TF et al. (1997) Regulation of neuronal survival by the serine-threonine protein kinase Akt. Science 275: 661-665

15. Tanti JF, Grillo S, Gremeaux T, Coffer PJ, Van Obberghen E, Le Marchand-Brustel Y (1997) Potential role of protein kinase $\mathrm{B}$ in glucose transporter 4 translocation in adipocytes. Endocrinology 138: 2005-2010

16. Kohn AD, Summers SA, Birnbaum MJ, Roth RA (1996) Expression of a constitutively active Akt Ser/Thr kinase in 3T3-L1 adipocytes stimulates glucose uptake and glucose transporter 4 translocation. J Biol Chem 271: 31372-31378

17. Ueki K, Yamamoto-Honda R, Kaburagi Y et al. (1998) Potential role of protein kinase $\mathrm{B}$ in insulin-induced glucose transport, glycogen synthesis and protein synthesis. J Biol Chem 273: 5315-5322

18. Calera MR, Martinez C, Liu H, Jack AK, Birnbaum MJ, Pilch F (1998) Insulin increases the association of Akt-2 with Glut4-containing vesicles. J Biol Chem 273: 7201-7204

19. Andjelkovic M, Jakubowicz T, Cron P, Ming XF, Han JW, Hemmings BA (1996) Activation and phosphorylation of a pleckstrin homology domain containing protein kinase (RAC-PK/PKB) promoted by serum and protein phosphatase inhibitors. Proc Natl Acad Sci USA 93: 5699-5704

20. Smith U, Sjostrom L, Bjorntorp P (1972) Comparison of two methods for determining human adipose cell size. J Lipid Res 13: 822-824

21. Klippel A, Reinhard C, Kavanaugh WM, Apell G, Escobedo MA, Williams LT (1996) Membrane localization of phosphatidylinositol 3-kinase is sufficient to activate multiple signal-transducing kinase pathways. Mol Cell Biol 16: 4117-4127

22. Franke TF, Kaplan DR, Cantley LC, Toker A (1997) Direct regulation of the Akt proto-oncogene product by phosphatidylinositol-3, 4-bisphosphate. Science 275: 665-668 
23. Marte BM, Rodriguez-Viciana P, Wennstrom S, Warne PH, Downward J (1997) R-Ras can activate the phosphoinositide 3-kinase but not the MAP kinase arm of the Ras effector pathways. Curr Biol 7: 63-70

24. Andjelkovic M, Alessi DR, Meier R et al. (1997) Role of translocation in the activation and function of protein kinase B. J Biol Chem 272: 31515-31524

25. Hemmings BA (1997) Akt signaling: linking membrane events to life and death decisions. Science 275: 628-630

26. Alessi DR, Andjelkovic M, Caudwell B et al. (1996) Mechanism of activation of protein kinase $B$ by insulin and IGF1. EMBO J 15: 6541-6551

27. Marte BM, Downward J (1997) PKB/Akt: connecting phosphoinositide 3-kinase to cell survival and beyond. Trends Biochem Sci 22: 355-358

28. Moule SK, Welsh GI, Edgell NJ, Foulstone EJ, Proud CG, Denton RM (1997) Regulation of protein kinase B and glycogen synthase kinase-3 by insulin and beta-adrenergic agonists in rat epididymal fat cells. Activation of protein kinase $\mathrm{B}$ by wortmannin-sensitive and -insensitive mechanisms. J Biol Chem 272: 7713-7719

29. Stephens L, Anderson K, Stokoe D et al. (1998) Protein kinase B kinases that mediate phosphatidylinositol 3,4,5-trisphosphate-dependent activation of protein kinase B. Science 279: 710-714

30. Downward J (1998) Mechanisms and consequences of activation of protein kinase B/Akt. Curr Opin Cell Biol 10: 262-267
31. Alessi DR, Deak M, Casamayor A et al. (1997) 3-Phosphoinositide-dependent protein kinase-1 (PDK1): structural and functional homology with the Drosophila DSTPK61 kinase. Curr Biol 7: 776-789

32. Delcommenne M, Tan C, Gray V, Rue L, Woodgett J, Dedhar S (1998) Phosphoinositide-3-OH kinase-dependent regulation of glycogen synthase kinase 3 and protein kinase B/AKT by the integrin-linked kinase. Proc Natl Acad Sci USA 95: 11211-11216

33. Smith U, Carvalho E, Rondinone C (1998) PKB inhibition prevents the insulin-stimulated increase in glucose transport and glut 4 translocation but not the antilipolytic effect in rat fat cells. Diabetes [Suppl 1] A46 (Abstract)

34. Kitamura T, Ogawa W, Sakaue H et al. (1998) Requirement for activation of the serine-threonine kinase Akt (protein kinase B) in insulin stimulation of protein synthesis but not of glucose transport. Mol Cell Biol 18: 3708-3717

35. Krook A, Roth RA, Jiang XJ, Zierath JR, Wallberg-Henriksson H (1998) Insulin-stimulated Akt kinase activity is reduced in skeletal muscle from NIDDM subjects. Diabetes 47: 1281-1286

36. Kim Y-B, Ciaraldi T, Nikoulina S, Henry R, Kahn B (1998) Insulin activation of akt/protein kinase $\mathrm{B}(\mathrm{PKB})$ is normal in spite of decreased activation of phosphoinositide 3-kinase (PI 3-kinase) in muscle of NIDDM subjects. Diabetes [Suppl 1] A7 (Abstract) 